\title{
TELAAH METODE PENGUJIAN AKTIVITAS ANTIOKSIDAN PADA DAUN TEH HIJAU (Camellia sinensis (L.) Kuntze)
}

\section{Study Of Antioxidan Activity Testing Methods Of Green Tea (Camellia sinensis (L.) Kuntze)}

\author{
Risma Aryanti I* \\ Farid Perdana 2 \\ Raden Aldizal Mahendra \\ Rizkio S. ${ }^{3}$ \\ *IProdi Farmasi, FMIPA, \\ Universitas Garut, Jawa Barat, \\ Indonesia \\ 2Prodi Farmasi, FMIPA, \\ Universitas Garut, Jawa Barat, \\ Indonesia \\ 3Prodi Farmasi, FMIPA, \\ Universitas Garut, Jawa Barat, \\ Indonesia \\ *email: \\ rismaaryantil I@gmail.com
}

\begin{abstract}
Abstrak
Teh hijau (Camellia sinensis (L.) Kuntze) merupakan minuman herbal yang banyak diminati karena memiliki banyak manfaat salah satunya sebagai antioksidan. Senyawa katekin dari golongan flavonoid (polifenol) dalam teh hijau diketahui bertanggung jawab dalam menentukan sifat antioksidan pada teh. Telah banyak penelitian yang dilakukan untuk mengukur aktivitas antioksidan pada teh hijau, sehingga diperlukan perbandingan metode pengujian aktivitas antioksidan untuk mengetahui metode mana yang paling baik berdasarkan perbedaan mekanisme aksinya. Metode pengujian aktivitas antioksidan yang digunakan diantaranya yaitu DPPH (I, I-diphenyl2-picrylhydrazyl), ABTS, FRAP (Ferric Reducing Antioxidant Power), CUPRAC (Cupric Reducing Antioxidant Capacity), dan ORAC (Oxygen Radical Absorbance Capacity). Hasil menunjukkan bahwa aktivitas antioksidan dalam teh hijau paling tinggi didapatkan dengan menggunakan metode ABTS yang dinyatakan dalam Trolox Equivalent yaitu sebesar $3210 \mu \mathrm{mol}$ TE/g dengan total fenol sebesar $240,73 \mathrm{mg} \mathrm{GAE} / \mathrm{g}$.
\end{abstract}

\begin{abstract}
Green tea (Camellia sinensis (L.) Kuntze) is a very popular herbal drink that because has many benefits, which one as an antioxidant. Catechin from the flavonoid class (polyphenols) in green tea is known as responsible for determining the antioxidant properties of tea. There were many research that measures antioxidant activity in green tea, so its have to compare the antioxidant activity testing method to see which one the method is better based on their mechanism in action. The antioxidant activity testing methods were used is DPPH $(I, I$ diphenyl-2-picrylhydrazyl), ABTS, FRAP (Ferric Reducing Antioxidant Power), CUPRAC (Cupric Reducing Antioxidant Capacity), and ORAC (Oxygen Radical Absorbance Capacity). The results showed that the highest antioxidant activity in green tea was obtained using the ABTS method that expressed in Trolox Equivalent, which is equal to $3210 \mu \mathrm{mol} T E / g$ with a total phenol of $240.73 \mathrm{mg}$ GAE / g.
\end{abstract} (C) year The Authors. Published by Institute for Research and Community Services Universitas Muhammadiyah Palangkaraya. This is Open Access article under the CC-BY-SA License (http://creativecommons.org/licenses/by-sa/4.0/) DOI: https://doi.org//0.33084/jsm.vxix.xxx.

\section{PENDAHULUAN}

Indonesia merupakan negara yang memiliki lahan luas dengan kondisi alam yang mendukung bagi pertanian dan perkebunan, serta dianugerahi keanekaragaman flora yang sebagian besar dapat dijadikan sebagai tanaman obat (Fajar et al., 20l8; Malik et al., 20l3).
Teh (Camellia sinensis (L.) Kuntze) merupakan jenis tanaman berkhasiat yang paling banyak dibudidayakan dengan baik di Indonesia (Fajar et al., 2018; Widyasanti et al., 2016). Teh banyak diminati dan hampir setiap hari dikonsumsi masyarakat sebagai minuman penyegar maupun minuman kesehatan, karena efek relaksasi yang ditimbulkan serta dipercaya memiliki segudang 
manfaat bagi kesehatan tubuh diantaranya sebagai antikanker, antioksidan, antijamur, antibakteri, dan mencegah penuaan (Falah, 2016; Malik et al., 2013; Natalia et al., 2018).

Teh dibagi menjadi beberapa jenis berdasarkan cara pembuatannya, diantaranya yakni teh hijau (tanpa fermentasi), teh oolong (semi-fermentasi), dan teh hitam (fermentasi total) (Nibir et al., 2017). Daun teh mengandung lebih dari 700 senyawa kimia, salah satunya yaitu katekin yang merupakan senyawa flavonoid golongan polifenol dan merupakan senyawa utama dalam teh yang bertanggung jawab terhadap sifat antioksidan teh (Falah, 2016; Purwanti, 2019; Susilo et al., 2012). Antioksidan merupakan zat yang dapat menangkal dan menghambat pembentukkan radikal bebas yang berbahaya bagi tubuh (Purwanti, 2019; Widyasanti et al., 2016).

Pengujian aktivitas antioksidan diperlukan untuk mengetahui aktivitas antioksidan dalam suatu sampel. Berbagai metode pengujian aktivitas antioksidan dapat menentukan karakteristik dari antioksidan pada sampel, sehingga dapat diketahui mekanisme kerja dari setiap antioksidan (Maryam et al., 2016). Pengujian aktivitas antioksidan non-enzimatik seperti polifenol dapat dilakukan berdasarkan perbedaan meknisme aksinya, diantaranya yaitu reaksi reduksi dengan radikal bebas atau dengan pengkhelatan ion radikal bebas melalui reaksi pembentukan kompleks (Rachman et al., 2017). Metode pengujian yang biasanya paling sering digunakan yaitu DPPH (I,I-diphenyl-2-picrylhydrazyl), FRAP (Ferric Reducing Antioxidant Power), ORAC (Oxygen Radical Absorbance Capacity), Total Phenolics Content, ABTS (2,2'-azino-bis(3-ethylbenzothiazoline-6sulphonic acid), CUPRAC (Cupric Reducing Antioxidant Capacity), TRAP (Total Radical Trapping Antioxidant
Parameter), TEAC (Trolox Equivalent Antioxidant Capacity) dan lain sebagainya (Sardarodiyan et al., 2016).

Atas dasar perbedaan cara kerja metode pengujian tersebut, maka tujuan dari review artikel ini yaitu untuk mengetahui metode pengujian aktivitas antioksidan yang paling baik pada daun teh hijau (Camellia sinensis (L.) Kuntze) dengan hasil yang dinyatakan dalam Trolox Equivalent dan total fenol.

\section{METODELOGI}

Penulisan review artikel ini dilakukan dengan menggunakan metode studi pustaka dimana kriteria inklusi jurnal yang digunakan yaitu jurnal nasional dan internasional yang terbit secara online serta berkaitan dengan teh hijau, aktivitasnya sebagai antioksidan, dan khususnya berbagai metode pengujian aktivitas antioksidan. Jurnal/pustaka diakses melalui mesin pencarian/google search seperti google scholarship, elsevier, asian journal of pacific dan lain sebagainya. Kriteria eksklusi jurnal yaitu jurnal yang dipilih minimal terbitan 10 tahun terakhir.

\section{HASIL DAN PEMBAHASAN}

Teh (Camellia sinensis (L.) Kuntze) merupakan tanaman yang banyak diminati dan menjadi konsumsi minuman kedua setelah air putih oleh hampir seluruh kalangan masyarakat karena dianggap memiliki banyak khasiat dan potensi yang baik bagi kesehatan tubuh salah satunya yaitu sebagai antioksidan, khasiat tersebut berasal dari kandungan senyawa yang terdapat didalamnya (Fajar et al., 2018; Juniaty, 2013; Sukina et al., 20I3). Kandungan terbesar dalam teh hijau yaitu senyawa flavonoid yang merupakan golongan senyawa polifenol (Mukty et al., 2018). Polifenol diketahui 
memiliki kemampuan penangkapan radikal bebas 100 kali lebih baik dibandingkan vitamin $C$ dan 25 kali lebih baik dibandingkan vitamin E (Shabri et al., 2016; Sukina et al., 2013). Senyawa polifenol (flavonoid) paling utama yang terkandung didalam teh hijau yaitu senyawa katekin (sekitar 90\% dari total polifenol) dimana senyawa EGCG (Epigallocatechin gallate) merupakan senyawa yang paling berperan aktif dalam katekin diantara senyawa lainnya (Amalia et al., 2016; Lee et al., 2014; Mukty et al., 2018). Senyawa katekin ini bertanggung jawab terhadap sifat teh hijau sebagai antioksidan untuk melindungi tubuh dari radikal bebas (Falah, 2016; Peel, 2020).

Pada teh hijau kandungan senyawa katekin lebih tinggi dari pada teh yang lain, karena teh hijau tidak melalui proses fermentasi (oksidasi enzimatis) yang dapat menurunkan atau bahkan merusak senyawa katekin didalam teh (Fajar et al., 2018). Proses pembuatan teh hijau setelah pemetikan yaitu dengan cara pengasapan, sehingga kandungan nutrisi dan senyawa antioksidan dalam teh hijau tidak rusak (Rahmanisa et al., 2016).

Kandungan polifenol (flavonoid) dalam teh hijau diketahui berpengaruh terhadap senyawa antioksidan dan aktivitas antioksidan dalam teh (Nishant et al., 2012). Hubungan antara aktivitas antioksidan dengan kandungan polifenol didalam teh hijau berbanding lurus, dimana semakin banyak kandungan polifenol (flavonoid) dalam teh maka semakin tinggi aktivitas antioksidannya (Fajar et al., 2018). Antioksidan adalah senyawa pendonor elektron yang dapat memutus reaksi oksidasi, sehingga tubuh dapat terlindungi dari bahaya radikal bebas penyebab terbentuknya stres oksidatif yang dapat memicu beberapa penyakit degeneratif seperti aterosklerosis, stroke, bahkan kanker (Natalia et al., 2018).
Aktivitas antioksidan dalam tumbuhan seperti dalam teh hijau dapat diuji dengan menggunakan beberapa metode pengujian, dalam praktiknya pengujian aktivitas antioksidan dikelaskan berdasarkan mekanisme kerjanya (reaksi kimianya) yaitu berbasis transfer elektron (Elektron Transfer Based) dan berbasis transfer atom hidrogen (Hidrogen Atom Transfer Based) (Gupta, 2015; Xiao et al., 2020). Metode berbasis HAT mengukur aktivitas antioksidan dalam menjebak radikal bebas dengan donasi atom hidrogen, diantaranya yaitu ORAC, TRAP, $\beta$-Caroten bleaching assay dan lain sebagainya (Gupta, 2015; Pisoschi et al., 2016). Sedangkan metode berbasis ET mengukur kemampuan reduktif antioksidan terhadap radikal bebas dengan mengandalkan transfer elektron, yang termasuk metode ini diantaranya FRAP, CUPRAC, FIC, DMPD dan sebagainya (Gupta, 2015; Pisoschi et al., 2016). Adapun DPPH, dan ABTS merupakan metode yang dianggap menggunakan kedua basis (HAT atau ET) (Pisoschi et al., 2016).

\section{Pengujian Aktivitas Antioksidan dengan Metode DPPH (I,I-diphenyl-2- picrylhydrazyl)}

Prinsip kerja dari metode DPPH yaitu reaksi oksidasi-reduksi (Purwanti, 2019). DPPH merupakan suatu radikal bebas sintetik yang dapat larut dalam senyawa polar seperti etanol dan metanol (Malik et al., 2013; Susilo et al., 20I2). DPPH akan bereaksi dengan dua cara yaitu mekanisme donor atom hidrogen dan donor elektron, dimana DPPH yang bersifat radikal akan mengambil atom hidrogen dari senyawa antioksidan untuk mendapatkan pasangan elektron (Apak et al., 2013; Malik et al., 2013). Adanya aktivitas antioksidan pada teh hijau ditandai dengan berubahnya warna ungu larutan 
DPPH menjadi warna kuning akibat tereduksinya DPPH oleh senyawa antioksidan sehingga menjadi DPPH-H (Falah, 2016; Malik et al., 2013; Molyneux, 2004). Perubahan warna ini berhubungan dengan jumlah elektron yang diterima DPPH dan menentukan seberapa kuat aktivitas antioksidan pada teh hijau ketika diukur intensitasnya dengan menggunakan spektrofotometer pada panjang gelombang 517 nm (Falah, 2016; Malik et al., 2013; Purwanti, 2019; Widyasanti et al., 2016).

DPPH merupakan metode pengujian antioksidan yang paling mudah, cepat, murah, dapat digunakan di laboratorium sederhana dan sensitif digunakan untuk menentukan aktivitas antioksidan (Purwanti, 2019). Namun metode ini sangat mudah terpengaruh oleh berbagai faktor, selain itu pelarut DPPH juga harus selalu dibuat baru (Ácsová et al., 2020). Senyawa polifenol dalam teh hijau memiliki gugus hidroksil yang atom hidrogennya akan diberikan kepada radikal bebas DPPH, sehingga DPPH yang bersifat reaktif karena memiliki elektron yang tidak berpasangan akan menjadi stabil. Semakin tinggi kandungan polifenol pada teh hijau maka semakin banyak elektron yang disumbangkan kepada radikal bebas, dan semakin tinggi pula aktivitas antioksidannya (Falah, 2016; Widyasanti et al., 2016).

Pada penelitian yang dilakukan oleh Aristizabal et al., (2015) dengan mengunakan metode DPPH pada 4 brand teh hijau yaitu Lipton, Oriental, Hindu, dan Jaibel dengan Trolox sebagai standar, diperoleh aktivitas antioksidan tertinggi pada merk Oriental yaitu sebesar II38,45 $\mu \mathrm{mol} \mathrm{TE} / \mathrm{g}$ sampel dengan kadar fenol total sebesar 127,74 mg GAE/g. Sedangkan aktivitas antioksidan paling rendah ditemukan pada merk Jaibel yaitu sebesar 93,76 $\mu \mathrm{mol} \mathrm{TE} / \mathrm{g}$ sampel dengan total fenol sebesar 748,09 mg GAE/g. Hasil tersebut menunjukkan perbedaan yang signifikan antara aktivitas antioksidan merk teh hijau Oriental dan Jaibel, hal itu dimungkinkan karena faktor perbedaan ukuran partikel teh yang mempengaruhi hasil ekstraksi, selain itu juga pengaruh perbedaan proses manufakturing yang digunakan oleh masing-masing industri pembuat teh (Aristizabal et al., 20I5)

\section{Pengujian Aktivitas Antioksidan dengan Metode ABTS (2,2'-azino-bis(3- ethylbenzothiazoline-6-sulfonic acid)}

ABTS merupakan metode pengujian
aktivitas/aktivitas antioksidan dengan menggunakan senyawa 2,2'-azino-bis(3ethylbenzothiazoline-6-sulfonic acid) sebagai penghasil radikal bebas (Oliveira et al., 20l4). ABTS adalah substrat dari enzim peroksidase yang dapat teroksidasi oleh peroksida $\left(\mathrm{H}_{2} \mathrm{O}_{2}\right)$ menjadi kation radikal (Windiawati et al., 20I5). Reagen ABTS memiliki ciri kimia yang stabil, dapat larut dalam air ataupun lemak (Windiawati et al., 2015). Prinsip metode ini yaitu melihat kemampuan senyawa antioksidan dalam menstabilkan radikal bebas dengan mendonorkan proton kepada radikal bebas yang ditandai dengan pemudaran warna dari warna biru kehijauan menjadi tidak berwarna seiring tereduksinya kation radikal ABTS (Shalaby et al., 2014; Sukweenadhi et al., 2020). Dalam pengujian aktivitas antioksidan dengan metode ABTS ini 
diperlukan reaksi oksidasi senyawa $A B T S$ terlebih dahulu oleh kalium persulfat $\left(\mathrm{K}_{2} \mathrm{~S}_{2} \mathrm{O}_{8}\right)$ untuk membentuk kation radikal $\mathrm{ABTS}\left(\mathrm{ABTS}^{++}\right)$yang selanjutnya direaksikan dengan senyawa antioksidan (Oliveira et al., 2014; Shalaby et al., 2014). Penghilangan warna serapan dapat diukur dengan menggunakan spektrofotometer pada panjang gelombang $734 \mathrm{~nm}$ (Sukweenadhi et al., 2020).

Metode ini baik digunakan untuk sistem yang berbasis air maupun organik, dengan waktu reaksi yang dibutuhkan lebih cepat, sederhana, serta dapat bekerja pada rentang $\mathrm{pH}$ yang luas (Apak et al., 2013; Susilo et al., 2012). Namun metode $A B T S$ ini sangat sensitif terhadap cahaya, pada saat pembentukan radikal $\mathrm{ABTS}^{++}$memerlukan waktu inkubasi 12-16 jam dalam kondisi gelap (Maryam et al., 2016).

Dari hasil penelitian yang dilakukan oleh Veljković et al. (2013) dengan menggunakan metode pengujian ABTS pada beberapa jenis teh dan Trolox sebagai pembanding diperoleh hasil pengukuran aktivitas antioksidan pada teh hijau sebesar $3210 \mu \mathrm{mol} T E / g$ dengan hasil total fenol sebesar 240,73 mg GAE/g. Hasil tersebut menunjukkan teh hijau memiliki kandungan fenol total paling tinggi diantara jenis teh yang lainnya, namun untuk hasil pengujian aktivitas antioksidan dengan metode ABTS ini tidak menunjukkan hasil yang paling baik diantara teh lainnya bahkan hasil pengujian menunjukkan nilai yang sama dengan hasil pengujian teh hitam (Veljković et al., 2013).

\section{Pengujian Aktivitas Antioksidan dengan Metode FRAP (Ferric Reducing Antioxidant Power)}

Prinsip penetapan aktivitas antioksidan dengan metode pengujian FRAP yaitu kemampuan antioksidan dalam mereduksi kompleks ferri $\left(\mathrm{Fe}^{3+}\right)$ dari ferri-tripyridyl-triazine (TPTZ) menjadi kompleks ferro $\left(\mathrm{Fe}^{2+}\right)$ yang ditandai dengan perubahan warna menjadi biru dan dapat diukur pada panjang gelombang $593 \mathrm{~nm}$ (Dontha, 2016; Jayanthi et al., 2011; Pires et al., 2017; Sukweenadhi et al., 2020). Reagen FRAP tidak berwarna terdiri dari campuran TPTZ, $\mathrm{FeCl}_{3} .6 \mathrm{H}_{2} \mathrm{O}$, dan dapar asetat (Sukweenadhi et al., 2020). Penambahan $\mathrm{FeCl}_{3} \cdot 6 \mathrm{H}_{2} \mathrm{O}$ diperlukan untuk membentuk senyawa kompleks $\mathrm{Fe}^{3+}$, dan penambahan dapar asetat karena reaksi biasanya terjadi pada pH asam yaitu 3,6 (Choirunnisa et al., 2016). Metode FRAP menggunakan senyawa antioksidan sebagai agen pereduksi (reduktan) dalam reaksi reduksi-oksidasi (Choirunnisa et al., 2016). Mekanisme kerja metode FRAP yaitu dengan cara menginaktivasi radikal bebas dengan transfer elektron (Jayanthi et al., 20I I).

FRAP merupakan metode pengujian yang sederhana, cepat, serta tanpa memerlukan alat khusus dalam pengukurannya (Jayanthi et al., 2011; Sukweenadhi et al., 2020). Namun kelemahan metode uji FRAP yaitu reagen bersifat kurang stabil sehingga harus dibuat baru dan harus segera digunakan, selain itu metode FRAP tidak spesifik dimana senyawa lain yang tidak memiliki kandungan antioksidan namun memiliki potensial reduksi rendah dari $\mathrm{Fe}^{3+} / \mathrm{Fe}^{2+}$ dapat terdeteksi oleh metode ini (Choirunnisa et al., 2016; Jayanthi et al., 201I; Sukweenadhi et al., 2020). 
Dari hasil penelitian yang dilakukan oleh Lee et al. (2014) menggunakan metode FRAP pada empat bagian daun teh hijau sesuai waktu pemetikannya dan Trolox sebagai pembanding, diperoleh hasil pengujian aktivitas antioksidan paling tinggi pada bagian daun ke empat/daun paling tua (Daejak) yang dipetik pada akhir bulan Mei yaitu sebesar 1697,81 $\mu \mathrm{mol}$ TE/g. Hasil pengujian aktivitas antioksidan paling rendah diperoleh pada bagian daun pertama (Woojeon) yang dipetik pada akhir bulan April yaitu sebesar I555,06 $\mu \mathrm{mol}$ TE/g. Dari hasil penelitian tersebut diketahui bahwa bagian daun/umur daun serta periode waktu pemetikan teh berpengaruh terhadap aktivitas antioksidan (Lee et al., 20l4).

\section{Pengujian Aktivitas Antioksidan dengan Metode CUPRAC (Cupric Reducing Antioxidant Capacity)}

Prinsip metode CUPRAC yaitu berdasarkan reaksi reduksi-oksidasi sederhana antara antioksidan dengan radikal bebas, yang dapat diukur melalui reduksi ion cupric $\left(\mathrm{Cu}^{2+}\right)$ menjadi cuprous $\left(\mathrm{Cu}^{+}\right)$dengan cara donor elektron oleh antioksidan (Dontha, 2016). Metode ini menggunakan pereaksi $\mathrm{Cu}(\mathrm{II})$-neokuproin $\left(\mathrm{Cu}^{2+}\right.$ $(\mathrm{Nc})_{2}$ ) sebagai oksidator/agen pengkhelat (Gülçin, 2012; Maryam et al., 2016). Adanya aktivitas antioksidan secara kualitatif ditandai dengan terjadinya perubahan warna kuning kecoklatan (Maryam et al., 2016). Hasil reaksi reduksi ion $\mathrm{Cu}^{2+}$ dapat diukur pada panjang gelombang 450 $\mathrm{nm}$ (Maryam et al., 2016).

Kelebihan dari metode CUPRAC yaitu pereaksi CUPRAC cukup selektif karena memiliki nilai potensial reduksi yang rendah, cepat, pereaksi lebih stabil, bisa didapat dari pereaksi lain (DPPH, ABTS), dapat digunakan untuk antioksidan yang bersifat hidrofilik atau lipofilik dalam $\mathrm{pH}$ fisiologis, selain itu metode ini mudah, sederhana, terpercaya, dengan sedikit biaya yang dibutuhkan, dan dapat digunakan di laboratorium konvensional dengan standar alat yang sederhana (Choirunnisa et al., 2016; Maryam et al., 2016).

Dari hasil penelitian yang dilakukan oleh Pekal et al. (20/2) dengan menggunakan metode CUPRAC dan trolox sebagai pembanding pada tiga jenis teh (teh hitam, teh hijau, dan teh buah) menunjukkan bahwa infusa teh hijau memiliki aktivitas antioksidan paling tinggi dari ketiga jenis teh tersebut dengan hasil tertinggi nilai teh hijau yang diperoleh yaitu sebesar $2710 \mu \mathrm{mol} \mathrm{TE} / \mathrm{g}$ dengan nilai total fenol sebesar 5/3,4 mg GAE/g (Pekal et al., 2012).

\section{Pengujian Aktvitas Antioksidan dengan Metode ORAC (Oxygen Radical Absorbance Capacity)}

Prinsip dasar metode ORAC ini yaitu mengukur kemampuan antioksidan dengan cara donor hidrogen dalam meredam radikal peroksil yang dilihat berdasarkan penurunan intensitas molekul fluoresen selama waktu reaksi (Aristizabal et al., 20I5; Gülçin, 20I2). Mekanisme kerja metode pengujian ini yaitu menggunakan inisiator bis azida/AAPH (2,2'-azobis(2-amidinopropane) dihydrochloride) sebagai pembentuk radikal peroksil lewat oksidasi, yang akan bereaksi dengan molekul fluoresen seperti fluorescein atau $\beta$-pikoeritrin dan menyebabkan hilangnya kemampuan berfluorosensi sebagai interpretasi dari kemampuan peredaman senyawa antioksidan 
terhadap radikal bebas (Gülçin, 20I2). Intensitas fluoresen akan menurun seiring berlangsungnya degenerasi oksidatif sebagai indikator dekomposisi fluoresen yang akan direkam selama setengah jam setelah penambahan AAPH, dan dapat diukur pada panjang gelombang $520 \mathrm{~nm}$ pada saat emisi dan $480 \mathrm{~nm}$ pada saat eksitasi (Gülçin, 20I2). Senyawa antioksidan dalam teh hijau dalam hal ini berperan melindungi molekul fluorosen dari degenerasi oksidatif, semakin sedikit senyawa antioksidan yang berpartisipasi maka semakin tinggi dekomposisi fluorosen dan semakin tinggi pula kehilangan sinyal fluorosensi (Ácsová et al., 2020; Gülçin, 2012).

Kelebihan metode ini yaitu cepat, rendah biaya, dapat digunakan untuk antioksidan yang bersifat hidrofilik maupun hidrofobik serta signifikan secara fisiologis (Aristizabal et al., 2015; Gülçin, 2012;). Kekurangan metode ini sulit dalam praktiknya, sensitif terhadap suhu rendah yang dapat menurunkan reproduktifitas pengujian (Ácsová et al., 2020; Gülçin, 20I2).

Berdasarkan hasil penelitian yang dilakukan oleh Aristizabal et al. (2014) dengan menggunakan metode ORAC pada empat jenis brand teh hijau yaitu Origin, Lipton, Hindu, dan Jaibel didapatkan hasil pengukuran aktivitas antioksidan paling tinggi pada brand teh Origin sebesar I588,05 $\mu \mathrm{mol}$ TE/g dan total fenol sebesar 127,74 mg GAE/g dengan hasil pengukuran brand teh Jaibel diketahui paling rendah yaitu sebesar 740,83 $\mu \mathrm{mol}$ TE/g dan hasil fenol total sebesar 93,76 mg GAE/g (Aristizabal et al., 2015).

Tabel I. Perbandingan hasil pengujian antioksidan dengan metode DPPH, ABTS, FRAP, CUPRAC, dan ORAC

\begin{tabular}{|c|c|c|c|c|c|}
\hline \multirow[b]{2}{*}{ Metode } & \multicolumn{2}{|c|}{ Hasil pengujian } & \multirow[b]{2}{*}{ Kelebihan } & \multirow[b]{2}{*}{ Kekurangan } & \multirow[b]{2}{*}{ Sumber } \\
\hline & $\begin{array}{c}\text { Total } \\
\text { fenol }(\mathrm{mg} \\
\text { GAE/g) }\end{array}$ & $\begin{array}{c}\text { Aktivitas } \\
\text { antioksidan } \\
(\mu \mathrm{mol} \mathrm{TE} / \mathrm{g})\end{array}$ & & & \\
\hline DPPH & 127,74 & II 38,45 & $\begin{array}{c}\text { Pengukuran sensitif, radikal bisa } \\
\text { direaksikan langsung dengan } \\
\text { antioksidan. }\end{array}$ & $\begin{array}{c}\text { Hanya untuk senyawa polar, reagen } \\
\text { harus selalu dibuat baru. }\end{array}$ & $\begin{array}{l}\text { Aristizabal } \\
\text { et al. }(20 \mid 5)\end{array}$ \\
\hline ABTS & 240,73 & 3210 & $\begin{array}{c}\text { Bisa digunakan untuk senyawa } \\
\text { hidrofilik/ lipofilik, bekerja pada } \\
\text { rentang } \mathrm{pH} \text { luas. }\end{array}$ & $\begin{array}{l}\text { Perlu dilakukan reaksi oksidasi } \\
\text { dahulu, waktu reaksi/inkubasi } \\
\text { pembentukan radikal lama. }\end{array}$ & $\begin{array}{l}\text { Veljković et } \\
\text { al. (20I3) }\end{array}$ \\
\hline FRAP & - & $|697,8|$ & $\begin{array}{c}\text { Sederhana, waktu yang diperlukan } \\
\text { cepat }\end{array}$ & $\begin{array}{c}\text { Reaksi tidak spesifik, bekerja pada } \\
\mathrm{pH} \text { asam. }\end{array}$ & $\begin{array}{l}\text { Lee et al. } \\
(20 \mid 4)\end{array}$ \\
\hline CUPRAC & 513,4 & 2710 & $\begin{array}{l}\text { Pereaksi CUPRAC selektif, lebih } \\
\text { stabil, dan bisa didapat dari pereaksi } \\
\text { lain, bisa digunakan untuk senyawa } \\
\text { hidrofilik/lipofilik, bekerja pada pH } \\
\text { fisiologis. }\end{array}$ & - & $\begin{array}{l}\text { Pekal et al. } \\
\quad(2012)\end{array}$ \\
\hline ORAC & 127,74 & 1588,05 & $\begin{array}{c}\text { Bisa digunakan untuk senyawa } \\
\text { hidrofilik/lipofilik, signifikan secara } \\
\text { fisiologis. }\end{array}$ & $\begin{array}{l}\text { Praktiknya sulit, sensitif terhadap } \\
\text { penurunan suhu }\end{array}$ & $\begin{array}{l}\text { Aristizabal } \\
\text { et al. (20|4) }\end{array}$ \\
\hline
\end{tabular}

Dari Tabel I. menunjukkan bahwa metode pengujian aktivitas antioksidan yang paling baik tanpa memperhatikan faktor yang mempengaruhi pengujian, ditunjukkan oleh metode ABTS dengan hasil yang diperoleh sebesar $3210 \mu \mathrm{mol} \mathrm{TE} / \mathrm{g}$ dengan total fenol sebesar $240,73 \mathrm{mg} \mathrm{GAE} / \mathrm{g}$.

Secara keseluruhan dari hasil pengujian aktivitas antioksidan, diketahui bahwa teh hijau memiliki 
kandungan senyawa antioksidan dan aktivitas antioksidan yang tinggi, baik berdasarkan cara donor hidrogen (HAT base) ataupun berdasarkan cara transfer elektron (ET base).

\section{KESIMPULAN}

Teh hijau (Camellia sinensis (L.) Kuntze) memiliki kandungan katekin (polifenol) sangat tinggi yaitu mencapai $90 \%$ dari seluruh total polifenolnya dan diketahui bertanggung jawab dalam sifat teh sebagai antioksidan. Untuk mengetahui aktivitas antioksidan dalam teh hijau digunakan beberapa metode pengujian/pengukuran berdasarkan mekanisme kerjanya (berbasis transfer hidrogen/transfer elektron) diantaranya yaitu metode DPPH, ABTS, FRAP, CUPRAC, dan ORAC. Hasil pengujian aktivitas antioksidan pada teh hijau paling tinggi diperoleh dengan menggunakan metode ABTS yaitu sebesar $3210 \mu \mathrm{mol} T E / g$ dengan total fenol sebesar $240,73 \mathrm{mg}$ GAE/g tanpa memperhatikan faktor yang mempengaruhinya. Penelitian lebih lanjut dengan variasi metode lebih banyak disarankan untuk mendapatkan hasil yang lebih spesifik dan jelas.

\section{UCAPAN TERIMA KASIH}

Reviewer mengucapkan terima kasih kepada semua pihak yang membantu dan mendukung terselesaikannya review jurnal ini.

\section{REFERENSI}

I. Fajar, R. I., Wrasiati, L. P., \& Suhendra, L. (20I8). Kandungan Senyawa Flavonoid Dan Aktivitas Antioksidan Ekstrak Teh Hijau Pada Perlakuan Suhu Awal Dan Lama Penyeduhan. Jurnal Rekayasa Dan Manajemen Agroindustri, 6(3), 196. https://doi.org/10.24843/jrma.2018.v06.i03.p02

2. Malik, A., Ahmad, A. R., \& Najib, A. (20/3). Daun Teh Hijau Dan Jati Belanda. Jurnal Fitofarmaka Indonesia, 4(2), 238-240.

3. Widyasanti A., Rohdiana D., E. N. (20/6).
AKTIVITAS ANTIOKSIDAN EKSTRAK TEH PUTIH (Camellia sinensis) DENGAN METODE DPPH $(2,2$ Difenil - I- Pikrilhidrazil). I(I), I-9.

4. Falah, S. (20I6). KETINGGIAN TEMPAT ANTIOXIDANT ACTIVITIES OF GMB 7 VARIETY OF TEA AT DIFFERENT ALTITUDE Balai Penelitian Tanaman Industri dan Penyegar Jalan Raya Pakuwon Km 2 Parungkuda, Sukabumi 43357 Indonesia Fakultas Matematika dan Ilmu Pengetahuan Alam , Departemen. 3, 53-60.

5. Natalia, F., Widyantika, D., Pengajar, S., Teknologi, J., Pertanian, H., Semarang, U., ... Semarang, U. (2018). METODE PENYEDUHAN DAN AKTIVITAS ANTIOKSIDATIF MINUMAN TEH (Camellia sinensis Linn .). 7, 24I-249.

6. Nibir, Y. M., Sumit, A. F., Akhand, A. A., Ahsan, N., \& Hossain, M. S. (2017). Comparative assessment of total polyphenols, antioxidant and antimicrobial activity of different tea varieties of Bangladesh. Asian Pacific Journal of Tropical Biomedicine, 7(4), 352-357. https://doi.org/10.1016/j.apjtb.2017.01.005

7. Purwanti, L. (2019). PERBANDINGAN AKTIVITAS ANTIOKSIDAN DARI SEDUHAN 3 MERK TEH HITAM (Camellia sinensis (L.) Kuntze) DENGAN METODE SEDUHAN BERDASARKAN SNI 0I-1902-1995. Jurnal Ilmiah Farmasi Farmasyifa, 2(1), 19-25. https://doi.org/10.293/3/jiff.v2il .4207

8. Maryam, S., Pratama, R., Effendi, N., \& Naid, T. (2016). DENGAN METODE CUPRIC ION REDUCING ANTIOXIDANT CAPACITY Fakultas Farmasi Universitas Muslim Indonesia , Makassar. Jurnal Fitofarmaka Indonesia, 2(I), 90-93.

9. Rachman, S. D., Mukhtari, Z., \& Soedjanaatmadja, R. U. M. . (2017). Chimica et Natura Acta. Chimica et Natura Acta, 5(3), 124-131. https://doi.org/10.24198/cna.v6.nI.|479|

10. Sardarodiyan, M., \& Mohamadi Sani, A. (2016). Natural antioxidants: sources, extraction and application in food systems. Nutrition and Food Science, 46(3), 363-373. https://doi.org/10.1 108/NFS-01-2016-0005

II. Juniaty Towaha, B. (20I3). KANDUNGAN 
SENYAWA KIMIA PADA DAUN TEH (Camellia sinensis). 19, 12-16.

12. Sukina B, Gwenny I.P, Suhartati, H. N. (20/3). KATEKIN DAUN TEH HIJAU (Camelia sinensis) TERHADAP MALONDIALDEHYDE DAN SUPER OXIDE DISMUTASE. 19, 65-139.

13. Mukty, I., Wirjatmadi, B., \& Purwanto, B. (2018). Pengaruh Pemberian Seduhan Teh Hijau (Camellia Sinensis ) Terhadap Aktivitas Superoksida Dismutase ( SOD ) Effect Of Green Tea (Camellia Sinensis ) Against Supeoxyde Dismutase ( SOD ) Activity. 207 I(September), I58-164.

14. Shabri, \& Rohdiana, D. (20/6). Optimasi dan Karakterisasi Ekstrak Polifenol Teh Hijau dari Berbagai Pelarut. Jurnal Penelitian Teh Dan Kina, 19(I), 57-66.

15. Lee, L. S., Kim, S. H., Kim, Y. B., \& Kim, Y. C. (2014). Quantitative analysis of major constituents in green tea with different plucking periods and their antioxidant activity. Molecules, 19(7), 91739186. https://doi.org//0.3390/molecules 19079173

16. Peel, O. (2020). Uji Aktivitas Antioksidan Kombinasi Ekstrak Etanol Daun Teh dan Kulit Jeruk Mandarin. 8(I), I-7. https://doi.org//0.528I/zenodo.388I55I

17. Rahmanisa, S., \& Wulandari, R. (2016). Pengaruh Ekstrak Teh Hijau terhadap Penurunan Berat Badan pada Remaja The Effect of Green Tea Extract in Decreasing Weight in Adolescent. Majority, 5(2), 109.

18. Gupta, D. (2015). Methods for determination of antioxidant capacity: A review. International Journal of Pharmaceutical Sciences and Research, 6(2),546566.

https://doi.org//0.13040/JJPSR.09758232.6(2).546$\underline{66}$

19. Xiao, F., Xu, T., Lu, B., \& Liu, R. (2020). Guidelines for antioxidant assays for food components. Food Frontiers, I(I),

60-69. https://doi.org/10.1002/fft2.10

20. Pisoschi, A. M., Pop, A., Cimpeanu, C., \& Predoi, G. (2016). Antioxidant capacity determination in plants and plant-derived products: A review. Oxidative Medicine and Cellular Longevity, 2016.

\section{https://doi.org//0.1155/2016/9130976}

2I. Apak, R., Gorinstein, S., Böhm, V., Schaich, K. M., Özyürek, M., \& Güçlü, K. (2013). Methods of measurement and evaluation of natural antioxidant capacity/activity (IUPAC technical report). Pure and Applied Chemistry, 85(5), 957998. https://doi.org/10.135I/PAC-REP-12-07-15

22. Molyneux, P. (2004). The use of the stable free radical diphenylpicryl- hydrazyl (DPPH ) for estimating antioxidant activity. 50(December 2003), $211-219$

23. Ácsová, A., Martiniaková, S., \& Hojerová, J. (2020). Selectedin vitro methods to determine antioxidant activity of hydrophilic/lipophilic substances. Acta Chimica Slovaca, 12(2), 200-21I. https://doi.org//0.2478/acs-2019-0028

24. Oliveira, S; Souza, G.A; Eckert, C.R; Silva, T.A; Edmar Silva Sobra, E.S; Fávero, O.P; Ferreira, M.J.P; Romoff, P; Baader, W. . (2014). EVALUATION OF ANTIRADICAL ASSAYS USED IN DETERMINING THE ANTIOXIDANT CAPACITY OF PURE Artigo. Quim. Nova, 37(3), 497-503.

25. Windiawati, Bina Lohita Sari, dan S. W. (20I5). AKTIVITAS ANTIOKSIDAN EKSTRAK ETANOL TEH PUTIH (Camellia sinensis L.) DAN BENALU TEH (Scurulla atropurpurea BL.Dans). I-8.

26. Shalabyl, E. A., \& * and Sanaa M. M. Shanab. (2014). African Journal of Pharmacy and Pharmacology Surfactants solubility, concentration and the other formulations effects on the drug release rate from a controlled-release matrix. 8(I3), 364-37I. https://doi.org//0.5897/AJPP20 I 3

27. Sukweenadhi, J., Yunita, O., Setiawan, F., Siagian, M. T., Danduru, A. P., \& Avanti, C. (2020). Antioxidant activity screening of seven Indonesian herbal extract. 2I(5), 2062-2067. https://doi.org// 0.13057/biodiv/d2 10532

28. Veljković, J. N., Pavlović, A. N., Mitić, S. S., Tošić, S. B., Stojanović, G. S., Kaličanin, B. M., ... Brcanović, J. M. (20I3). Evaluation of individual phenolic compounds and antioxidant properties of black, green, herbal and fruit tea infusions consumed in Serbia: Spectrophotometrical and 
electrochemical approaches. Journal of Food and Nutrition Research, 52(I), 12-24.

29. Dontha, S. (2016). A review on antioxidant methods. Asian Journal of Pharmaceutical and Clinical Research,9(2), 14-32. https://doi.org/I0.22I59/ajpcr.2016.v9s2.13092

30. Pires, M. A., Munekata, P. E. S., Villanueva, N. D. M., Tonin, F. G., Baldin, J. C., Rocha, Y. J. P., ... Trindade, M. A. (2017). The Antioxidant Capacity of Rosemary and Green Tea Extracts to Replace the Carcinogenic Antioxidant ( BHA) in Chicken Burgers. 2017.

31. Choirunnisa, A. R., Fidrianny, I., \& Ruslan, K. (2016). Comparison of Five Antioxidant Assays for Estimating Antioxidant Capacity from Three Solanum SP. Extracts. Asian Journal of Pharmaceutical and Clinical Research, 9, 123-128. https://doi.org/10.22159/ajpcr.2016.v9s2.13155

32. Jayanthi, P., \& Lalitha, P. (20II). Reducing power of the solvent extracts of Eichhornia crassipes (Mart.) Solms. International Journal of Pharmacy and Pharmaceutical Sciences, 3(SUPPL. 3), 126-128.

33. Pekal, A., Drozdz, P., \& Pyrzynska, K. (20I2). Comparison of the antioxidant properties of commonly consumed commercial teas. International Journal of Food Properties, 15(5), II0I1109.

https://doi.org//0.1080/|09429|2.2010.5|4642

34. Gülçin, I. (20I2). Antioxidant activity of food constituents: An overview. Archives of Toxicology, 86(3), 345-39l. https://doi.org//0.1007/s00204$011-0774-2$

35. Anand Jigisha, Rai Nishant*, K. N. and G. P. (2012). Green tea: A magical herb with miraculous outcomes Review Article GREEN TEA: A MAGICAL HERB WITH MIRACULOUS OUTCOMES Anand Jigisha , Rai Nishant *, Kumar Navin and Gautam Pankaj. 3(May), I39-I48.

36. Fryda Amalia, Nana Sutisna Achyadi, A. D. S. (2016). PENGARUH GRADE TEH HIJAU DAN KONSENTRASI GULA STEVIA (Stevia rebaudiana bertoni M.) TERHADAP KARAKTERISTIK SIRUP TEH HIJAU (GREEN TEA). I-12.
37. Haryato Susilol, Dwi Indriati2, A. R. (20I2). I , 2 , 3 I. 2(2), 126-136.

38. Ramiréz-Aristizabal, L. S., Ortiz, A., \& OspinaOcampo, L. F. (2015). Evaluation of the antioxidant capacity and characterization of phenolic compounds obtained from tea (Camellia sinensis) for products of different brands sold in Colombia. Pharmacologyonline, 3(2015DECEMBER), I49-159. 